\title{
A Review on the Significance of Local Plan for Coastal Reclamation Development: The Case of Malacca, Malaysia
}

\author{
Nor Syafa'ah Ishak', a, Mohammad Yusup ${ }^{2}$, Ahmad Fuzi Arshad ${ }^{3}$ and Yusfida Ayu Abdullah ${ }^{4}$ \\ ${ }^{1}$ Centre of Postgraduate Studies of Town and Regional Planning, Faculty of Architecture, Planning and Surveying, 40450 UiTM Shah Alam, \\ Selangor, Malaysia \\ ${ }^{2,384}$ Centre of Studies of Town and Regional Planning, Faculty of Architecture, Planning and Surveying, 40450 UiTM Shah Alam, Selangor, \\ Malaysia
}

\begin{abstract}
A Development Plan acts as a planning and controlling instrument that helps to guide in decision making of current and future development. Therefore, in the Malaysian Town and Country Planning Act 1976 (Act 172), the provision of development plan from each level of the planning administration is stated in the Act under Section 6B till Section 16B. In examining the significance of one of the many development plans in Malaysia, i.e. the local plan, this paper therefore, focuses on the provision of a local plan by the Local Planning Authority (LPA) of the said area. This paper, thus, aims to evaluate the Central Malacca Local Plan since Malacca is currently experiencing rapid growth in development along the coastal area. The primary data was obtained from interviews with the related planning authorities via face-to-face method. While, secondary data was gathered from related legal documents, policies and guidelines, as well as the existing development plan for the purpose of an in-depth data. Findings revealed incapability of the existing local plan to assist the development control in deciding the planning permission for reclaimed area. The existing local plan shows no zoning for coastal reclamation area because of the rapid growing development and time consuming procedure to amend the local plan according to the Act 172. In addition, the Act 172 and the process in amending the local plan should be more flexible and able to address the current issue efficiently. Finally, the paper concludes with a suggestion for further exploration in order to achieve an operative development process and functioning practice of the local plan.
\end{abstract}

\section{Introduction}

To date, urbanisation processes are in line with the rapid development of residential, commercial and industrial mainly and it has gradually led towards the scarcity of land. Land is a scarce resource [1]. Therefore, the demands for more land are arising. Many developed countries had already practices coastal reclamation for decades such as Singapore, Japan and Hong Kong in order to tackle problems regarding scarcity of land [2]. At present, similar situation prevails in Malaysia [2]. Malaysia has been experiencing rapid urbanisation process from the economic development, industrialisation, and enormous migrations, along with the natural population growth [3]. In coping with the urbanisation process, the development had taken place almost everywhere. Recently, Malaysia also focuses on the development for reclamation in coastal area. There are three states in West Malaysia that commit in the development of coastal reclamation, namely, Pulau Pinang, Malacca and Johor. Nevertheless, this study only selects Malacca as its study area. The reason for choosing Malacca is due to its speciality as a historical city and its status as a UNESCO site. The State of Malacca is located in the southern part of West Malaysia. It covers an area of

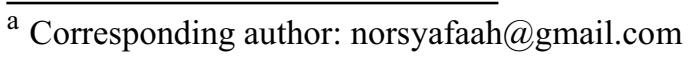

$1,799 \mathrm{~km}^{2}$ [4]. The case study is located from Tanjung Kling up to Telok Mas along the Straits of Malacca. The coastal reclamation development projects are concentrated along the coastal areas of the Straits of Malacca including Pantai Klebang, Pekan Klebang, Taman Kota Laksamana, Pulau Melaka, Permatang Pasir Permai and Telok Mas [5]. The responsible local authority for this coastal reclamation site is the Malacca Historical City Council administrative area [6].

\section{Research Methodology}

This paper concentrates on the impact of local plan in the coastal reclamation development. A local plan plays an important role in planning and development especially for a new area. Therefore, this study employs the qualitative research method and a case study design. Qualitative research is concerned with the subjective assessment including attitudes, opinions and behaviour or it is also called as qualitative phenomenon [7]. Accordingly, Shamsuri [8] claimed that qualitative research is not meaningful if it is being expressed by numbers. The case study approach is suitable for a smallscale study [9]. It is an extensive study of a particular 
case and it can be considered as research strategy rather than a method of data collection [10]. Meanwhile, this study attempted in improving the planning process for coastal reclamation in Malacca including the local plan as a tool for development control. The primary data will be obtained from the government agencies that are directly involved with the coastal reclamation development such as Malacca Historical City Council, Malacca Economy Planning Unit, Malacca Department of Town and Country Planning and other related agencies. The data was gathered through face-to-face interview conducted in order to gain further understanding related to the study as well as opinion and recommendation on the provision of the local plan and planning process from the experts. Hence, the study applies the purposive sampling in getting the response and feedback from the informants through interviews. Additionally, secondary data was gathered from various development plans, legal documents, policies, and other related. This is vital as it is intended to obtain a clearer picture on the current issues and problems associated with coastal reclamation practice in Malacca and thereafter to suggest solutions for the current practice and development of coastal reclamation.

\section{The Key Terminologies}

Planning is being expressed as something futuristic [11]. According to Stewart, Rutherford, Levy and Jackson [12], planning is the process to determine what is to be attained in the future and clarifying the steps required in achieving it. Also, referring to the planning definition by Keeble [13] and Ratchliffe [14], Yusup [15] had then concluded his planning definition as a process of decision making involving a goal, target group as well as correct procedures. Meanwhile, Zainol et al. [16] defines the term of planning as a physical performance and space of maps, drawings, reports as well as other form of documentation and plan that deliver detail description, concept and idea of a planned development for the current and future. For that reason, a good planning acts as a mould towards a good development for current and future goodness.

As stated in Section 5 of the National Land Code 1965 (NLC) (Act 56) [17] as well as in Section 2 of the Town and Country Planning Act 1976 (Act 172) [18], the term of 'land' is being interpreted as the land that covered on and below the surface of the earth and its substances, all vegetation and other natural products either it is on or below the surface, all things that attached to the earth, the land that is covered by water and any estate or interest in, or right over are considered as 'land'. The land is under the state matter and it is clearly being mentioned in the List II (State Lists) under Ninth Schedule of the Federal Constitution that the state government is the party which has full responsibility towards the land matter within its territory [19]. The land use planning is a state issue and the federal government is responsible to take on a supervisory role with the overall land use planning activity and this system is also being introduced to express the authority's intention in initiating, encouraging and controlling over the physical, economic, environmental and social changes in a particular area [20;18]. The land use planning signifies the way of planning the physical layout, or land use, of the communities and is the key component of a community's long term resilience [21]. This indicates that planning for the use of land in advance is important especially in avoiding the conflict of land use, thus, aids in guiding towards a sustainable development.

In Section 2(1) of the Town and Country Planning Act 1976 (Act 172), it has been highlighted that 'development' is the carrying out of any building, engineering, mining, industrial or other similar operation in, on, or under land, the making of any material change in the use of any land or building or any part thereof, or the subdivision or amalgamation of lands: and 'develop' shall be construed accordingly. Additionally, Ahmad and Bajwa [22] claimed that development embraces all types of building, entirely a new construction, demolition and reconstruction or addition and alteration of a building including residential, commercial, industrial and others, named as development. This was clearly spelled in Section 19(1) of the Act 172. Hence, the development is considered as the activity that being performed physically and apparently involving the changes to the building or land as well as affecting the surrounding.

The term 'coast' is being defined by the Malaysia Department of Irrigation and Drainage [23] as the strip of land which extends from the coastline inland to the first major change in the terrain features, therefore, it is not influenced by the coastal process. Apart from that, according to Powter [24], reclamation is the process of reconverting disturbed land to its former or other productive uses. Hence, the terms of coastal reclamation basically came from both stated terms to be interpreted broadly. The coastal reclamation is being mentioned by Sufian and Mustafa [25] as taken place within the area that defines as foreshore (in Section 5 of the National Land Code 1965 (Act (56)) and it is located within the area inside the baseline that is as internal waters, whereby waters within 12 nautical miles from the baseline are territorial waters and those within 200 nautical miles seawards from the baseline are the Exclusive Economic Zone. Therefore, the first 3 nautical miles of the territorial waters from the low water mark is under the jurisdiction of the state, while the rest of the area is rest on the federal jurisdiction. Additionally, coastal reclamation is the land that seems to appear out of nowhere [26]. Coastal reclamation can be considered as common practices in producing valuable land in the coastal areas [27]. Thus, the coastal reclamation is a way to obtain completely a new land.

As a development control instrument, the development plan is a prerequisite at every level of government. In Act 172, the development plan is in relation to an area, it is either the local plan of the area, and otherwise, if there is no local plan for the area; only then the structure plan will be effective to be used as guidance for development. The development plans considered as a legal requirement for all upper-level till lower-level governments [28]. The development plan is the plan that acts as guidance in locating development with criteria based policies [20]. Each of the development 
plans provided, it play functions as a guideline and reference in every aspect of the urban planning [15]. The local plan also is one of the instruments used in the decision making process [29].

\section{The Local Authority Administrative Area}

The Local Government Act 1976 (Act 171) is one of the main legislations exercised by local authorities to facilitate the development within their area. The Act 171 outlines the form, organisational structure, duties and responsibilities of the local authority as a whole especially in terms of accountability pertaining to town and country planning [30]. In Section 3 of the Act 171, it indicates on the declaration and determination of an area to be under any local authority that shall administrate the declared area. Any land or area that are still not be declared or gazetted under any local authority administrative area, will still be under the state matter the state authority responsibility [19]. Section 4 of the Act 171 mentioned on the alteration and determination of the boundaries. The alteration of the boundaries requires the state authority to specify the boundary of a local authority from state authority land or area. The declaration and gazetting of the area for a local authority is important because the respective local authority will be aware of their administrative area. Furthermore, the provision of a local plan by the local planning authority will need to specify the boundary of the local plan for development. Thus, as an example, the coastal reclamation area in Malacca has been declared and it falls under the Malacca Historical City Council, therefore, the Malacca Historical City Council shall provide a detail plan concerning on the area due to its rapid development on the reclamation area [31]. A plan should be as detail as possible because it will help in directing the development [6].

\section{The Provision of Local Plan in Act 172}

Malaysia consists of three-level of government administration system; federal government, state government and the local authority [32]. Each level of the government administration system has its own development plan that must be prepared in assisting a good planning towards a sustainable physical development. In Malaysia, development plans consist of four types through the three levels of planning administration and is stated in Part III of the Act 172 on the provision of development plan (Table 1).

However, this study will only focus on the provision of a local plan at the local level which is the local authority's area. Local authority is the lowest level in the hierarchy of government systems within the concept of federalism [33]. The local authority is defined as a subnational in the government's level which only has its jurisdiction over a limited range of the state functions, within a designated geographical area which is part of a larger territory [34].
Table 1. The Jurisdiction in Providing Development Plan in Malaysia under the Act 172

\begin{tabular}{|c|c|c|c|}
\hline $\begin{array}{c}\text { Level of } \\
\text { government } \\
\text { administration }\end{array}$ & $\begin{array}{c}\text { Type of } \\
\text { development } \\
\text { plan }\end{array}$ & $\begin{array}{l}\text { Section } \\
\text { involved }\end{array}$ & Jurisdiction \\
\hline Federal & $\begin{array}{l}\text { National } \\
\text { Physical } \\
\text { Plan (NPP) }\end{array}$ & $\begin{array}{l}\text { - Section } \\
6 \mathrm{~B}\end{array}$ & $\begin{array}{lr}\text { - } \text { Negotiated r with } \\
\text { State Authority } \\
\text { (SA) } \\
\text { - Approved r by } \\
\text { National } & \text { Physical } \\
\text { Planning } & \text { Council } \\
\text { (NPPC) } & \\
\text { - Prepared r by } \\
\text { Director General } \\
\text { (DG) of } & \text { Federal } \\
\text { Town and } & \text { Country } \\
\text { Planning } & \\
\text { Department }\end{array}$ \\
\hline State & $\begin{array}{l}\text { Structure } \\
\text { Plan (SP) }\end{array}$ & $\begin{array}{l}\text { - Section } \\
7- \\
\text { Section } \\
11\end{array}$ & $\begin{array}{l}\text { - Approved by State } \\
\text { Planning } \\
\text { Committee (SPC) } \\
\text { - Assented by the } \\
\text { State Authority } \\
\text { (SA) } \\
\text { - Prepared by the } \\
\text { State Director of } \\
\text { Town and Country } \\
\text { Planning } \\
\text { Department }\end{array}$ \\
\hline \multirow[b]{2}{*}{ Local } & $\begin{array}{l}\text { Local Plan } \\
\text { (LP) }\end{array}$ & $\begin{array}{l}\text { - Section } \\
12- \\
\text { Section } \\
16 \mathrm{~A}\end{array}$ & $\begin{array}{l}\text { - Approved by State } \\
\text { Planning } \\
\text { Committee (SPC) } \\
\text { - Assented by State } \\
\text { Authority (SA) } \\
\text { - Prepared by Local } \\
\text { Planning Authority } \\
\text { (LPA) }\end{array}$ \\
\hline & $\begin{array}{l}\text { Special Area } \\
\text { Plan (SAP) }\end{array}$ & $\begin{array}{l}\text { - Section } \\
16 \mathrm{~B}\end{array}$ & $\begin{array}{l}\text { - Approved by State } \\
\text { Planning } \\
\text { Committee (SPC) } \\
\text { - Assented by State } \\
\text { Authority (SA) } \\
\text { - Prepared by Local } \\
\text { Planning } \\
\text { Authority/State } \\
\text { Director }\end{array}$ \\
\hline
\end{tabular}

Additionally, in Section 5 of the Act 172, stated that the local authority may also act as the local planning authority (LPA) within their particular area. The LPA's functions including; i) regulating, controlling and plan over the development and the use of all land and building within their administrative area; ii) undertake, assist in, and encourage the collection, maintenance, and publication of statistics, bulletins, and monographs, and other publications that are related to town and country planning and its methodology; also iii) performing other functions as the State Authority or Committee may from time to time assign to it [18]. Besides, as in the Act 172 (Section 12(1)), the LPA also is the responsible party that should provide a local plan for its area. Whereas, in Section 5(2) of the Act 172 stated that the area which is not under any local authority area, is then required by the State Director of the State Department of Town and Country Planning to provide a local plan of the particular area. 


\subsection{The Preparation of a Local Plan by the Local Planning Authority (LPA)}

The provision to provide a local plan by a local planning authority of the area is being pointed out in Section 12(1) of the Act 172. In preparing a local plan, there are procedures and requirement that should be adhered by the LPA as in Table 2. Furthermore, there are five (5) situations that require the preparation of a local plan based on Act 172 which are; i) the LPA preparing the draft local plan during the draft structure plan is being prepared or before the State Planning Committee (SPC) approves or rejects the draft structure plan; ii) the Director of State Department of Town and Country Planning preparing the draft local plan of its area as appointed by the LPA as in Section 5(2) of Act 172 (the area which is outside of any local authority administrative area; iii) the LPA preparing a draft local plan when the structure plan of their area has been enforced; iv) the LPA preparing a draft local plan when instructed by the SPC; and v) the Director of State Department of Town and Country Planning preparing a draft local plan if instructed by the SPC by the reason of the LPA of the area are unable to prepare a draft local plan for their area [35]. This indicates that the provision of a local plan of any respective area either with or without a local authority to administrate the area, the local plan of the area will still need to prepare the local plan to control over the development that takes place within its area

Therefore, the process in preparing a local plan consists of four (4) stages called mobilisation, draft local plan preparation period, publicity and public participation, and approval and gazette the draft local plan as illustrated in Figure 1. The overall process demonstrates on how a local plan being prepared in details. In addition, the time frame for a local plan to be effective after it has been gazette is between 10 till 15 years [35]. However, the local plan can be reviewed from time to time if it is required, depending on the necessity for it to be modified [35].

\subsection{The Weakness of the Local Plan in Assisting Development Control System}

There are several problems in the provision of a local plan in Malaysia including the Central Malacca region. Firstly, the weakness from the upper-level administration and their provision of the development plan which are the National Physical Plan and the State Structure Plan in providing policy, guidelines, strategic development and other relevant provisions are the root of the weakness in the provision of local plan [36]. Due to that matter, local plan cannot interpret the policy and guidelines and in detailing other relevant information to control the development for building and land [29]. This problem is because of the incompetence of the local plan especially in controlling over the development within its boundary. Also, the duration in preparing a local plan takes a longer time (Figure 1).
Table 2. The Provision of Local Plan as in Act 172

\begin{tabular}{|c|c|c|c|}
\hline \multicolumn{2}{|c|}{ Aspect } & $\begin{array}{l}\text { Section } \\
\text { involved }\end{array}$ & Description of provision \\
\hline \multirow{6}{*}{$\begin{array}{l}\text { Responsible } \\
\text { authority }\end{array}$} & \multirow{4}{*}{$\begin{array}{l}\text { The Local } \\
\text { Planning } \\
\text { Authority } \\
\text { (LPA) }\end{array}$} & $\begin{array}{l}\text { Section } \\
12(1)\end{array}$ & $\begin{array}{l}\text { The local plan must be provided by LPA of the area if it } \\
\text { is required and it will give benefit to the area. There are } \\
\text { two (2) situations which LPA can prepare the draft } \\
\text { local plan, when draft structure plan is being prepared } \\
\text { or before the draft structure plan assented by SPC. }\end{array}$ \\
\hline & & $\begin{array}{l}\text { Section } \\
12(2)\end{array}$ & $\begin{array}{l}\text { LPA should provide a draft local plan for the whole of } \\
\text { its area immediately if the structure plan of the state has } \\
\text { been effectively enforced. }\end{array}$ \\
\hline & & $\begin{array}{l}\text { Section } \\
12(6)\end{array}$ & $\begin{array}{l}\text { LPA also must provide a draft local plan of their area as } \\
\text { instructed by SPC. This instruction can be given during } \\
\text { or after the preparation of draft structure plan. }\end{array}$ \\
\hline & & $\begin{array}{l}\text { Section } \\
16(1)\end{array}$ & $\begin{array}{l}\text { LPA has the right to make alteration, revocation and } \\
\text { replacement of the local plan with another local plan. }\end{array}$ \\
\hline & \multirow{2}{*}{$\begin{array}{l}\text { The } \\
\text { Director of } \\
\text { State } \\
\text { Departmen } \\
\text { tof Town } \\
\text { and } \\
\text { Country } \\
\text { Planning }\end{array}$} & $\begin{array}{l}\text { Section } \\
5(2)\end{array}$ & $\begin{array}{l}\text { The Director of the State Department of Town and } \\
\text { Country Planning shall prepare a local plan for any area } \\
\text { which located outside the local authority boundary. }\end{array}$ \\
\hline & & $\begin{array}{l}\text { Section } \\
16 \mathrm{~A}(1)\end{array}$ & $\begin{array}{l}\text { The SPC may instruct the Director of the State } \\
\text { Department of Town and Country Planning to prepare } \\
\text { local plan if LPA is unable to prepare local plan. }\end{array}$ \\
\hline \multirow{2}{*}{\multicolumn{2}{|c|}{ Form }} & $\begin{array}{l}\text { Section } \\
12(3)\end{array}$ & $\begin{array}{l}\text { A draft local plan should consist of map and written } \\
\text { statement. }\end{array}$ \\
\hline & & $\begin{array}{l}\text { Section } \\
12(4)\end{array}$ & $\begin{array}{l}\text { A draft local plan must be supported by diagrams, } \\
\text { illustrations and descriptive matter as it is appropriate } \\
\text { to be included in explaining and illustrating the local } \\
\text { plan. }\end{array}$ \\
\hline \multicolumn{2}{|l|}{ Content } & $\begin{array}{l}\text { Section } \\
12(3)(a) \\
\text { and }(b)\end{array}$ & $\begin{array}{l}\text { The content of the local plan shall include all } \\
\text { appropriate maters that are relevant to be documented } \\
\text { in the local plan such as the land use zoning } \\
\text { (residential, commerciall industrial, agriculture, etct), } \\
\text { type of development (existing and proposed), } \\
\text { protection and improvement of the physical } \\
\text { development, preservation of the natural topography, } \\
\text { improvement of the landscape, the preservation and } \\
\text { planting trees, making up open spaces, preservation and } \\
\text { enhancement of character and appearance of buildings, } \\
\text { improvement of communications and management of } \\
\text { traffici in the local plan area. As well, other matters } \\
\text { specified or instructed by SPC. }\end{array}$ \\
\hline \multirow{12}{*}{ Preparation } & & $\begin{array}{l}\text { Section } \\
12 \mathrm{~A}\end{array}$ & $\begin{array}{l}\text { Before commencing the preparation of local plan, the } \\
\text { LPA shall give opportunity to the person to make } \\
\text { representations in respect of matters such as objection } \\
\text { and matters that should be included in the local plan. }\end{array}$ \\
\hline & \multirow{3}{*}{$\begin{array}{l}\text { Publicity } \\
\text { of draft } \\
\text { local plan }\end{array}$} & $\begin{array}{l}\text { Section } \\
13(1)\end{array}$ & $\begin{array}{l}\text { LPA must provide copies of draft local plan for } \\
\text { inspection and details of place and time of the publicity. }\end{array}$ \\
\hline & & $\begin{array}{l}\text { Section } \\
13(2)\end{array}$ & $\begin{array}{l}\text { LPA shall notify notice regarding the draft local plan } \\
\text { that has been available for public inspection in three (3) } \\
\text { issues - two (2) in the local newspaper and either one } \\
\text { (1) must be in national language. The notice must } \\
\text { include time and place that are available for inspection. } \\
\text { The inspection period is not less than four (4) weeks } \\
\text { any objection or representations can be made to the } \\
\text { LPA. }\end{array}$ \\
\hline & & $\begin{array}{l}\text { Section } \\
13(3)\end{array}$ & $\begin{array}{l}\text { Time for inspection of draft local plan can be extended } \\
\text { by LPA by not more than four week on the application } \\
\text { of any person. }\end{array}$ \\
\hline & $\begin{array}{l}\text { Inquiries, } \\
\text { objection } \\
\text { and } \\
\text { hearing } \\
\end{array}$ & $\begin{array}{l}\text { Section } \\
14(1)\end{array}$ & $\begin{array}{l}\text { A Committee (three persons) shall be appointed by SPC } \\
\text { as directed by LPA to hold local inquiries or other } \\
\text { hearing. }\end{array}$ \\
\hline & \multirow{7}{*}{$\begin{array}{l}\text { Approval } \\
\text { or rejection } \\
\text { of ddat } \\
\text { local plan }\end{array}$} & $\begin{array}{l}\text { Section } \\
15(1)\end{array}$ & $\begin{array}{l}\text { After modifications along with consideration of the } \\
\text { objections, LPA will submit the draft local plan (that } \\
\text { has been changed) to SPC for approval. }\end{array}$ \\
\hline & & $\begin{array}{l}\text { Section } \\
15(1 \mathrm{~A})\end{array}$ & $\begin{array}{l}\text { SPC has the right to approved, whole or a part of draft } \\
\text { local plan with or without modifications, or reject. }\end{array}$ \\
\hline & & $\begin{array}{l}\text { Section } \\
15(1 \mathrm{~B})\end{array}$ & $\begin{array}{l}\text { SPC may take into account any matters that it thinks are } \\
\text { relevant, whether or not they were taken into account in } \\
\text { the plan as submitted or resubmitted to SPC. }\end{array}$ \\
\hline & & $\begin{array}{l}\text { Section } \\
15(1 \mathrm{C}) \\
\end{array}$ & $\begin{array}{l}\text { SPC shall submit the approved draft local plan to the } \\
\text { State Authority to be assented and come into effect. }\end{array}$ \\
\hline & & $\begin{array}{l}\text { Section } \\
15(4)\end{array}$ & $\begin{array}{l}\text { LPA must publish the facts that the draft local plan of } \\
\text { the area has been assented in the State Gazette with the } \\
\text { minimum of two (2) local newspaper and either one (1) } \\
\text { of them are publish in national language. }\end{array}$ \\
\hline & & $\begin{array}{l}\text { Section } \\
15(5)\end{array}$ & $\begin{array}{l}\text { Local plan shall conform to the structure plan. If there } \\
\text { exists a difference in the provision between these two } \\
\text { development plan of the state, and the Committee is } \\
\text { satisfied that the existing structure plan of the state is } \\
\text { out-of-date, the Committee must refer to other State } \\
\text { Authority for its decision. }\end{array}$ \\
\hline & & $\begin{array}{l}\text { Section } \\
15(6)\end{array}$ & $\begin{array}{l}\text { If the State Authority is satisfied with the matter } \\
\text { mention in Section } 15(5) \text {, the State Authority shall } \\
\text { notify it in the State Gazette, declaring the local plan of } \\
\text { the area shall prevail over the structure plan as regards } \\
\text { to that particular provision. }\end{array}$ \\
\hline \multirow{2}{*}{\multicolumn{2}{|c|}{ Review and monitoring }} & $\begin{array}{l}\text { Section } \\
16(1)\end{array}$ & $\begin{array}{l}\text { LPA may at any time make proposals of the local plan } \\
\text { in respect of alteration, revocation, or replacement. }\end{array}$ \\
\hline & & $\begin{array}{l}\text { Section } \\
16(3)\end{array}$ & $\begin{array}{l}\text { Subsections } 12(8) \text { and }(9) \text {, and sections } 13 \text { (publicity), } \\
14 \text { (inquiries and hearings) and } 15 \text { (approval or } \\
\text { rejection), shall apply in relation to the making of } \\
\text { proposals for the alteration, revocation, or replacement } \\
\text { of a local plan. }\end{array}$ \\
\hline
\end{tabular}


STAGE

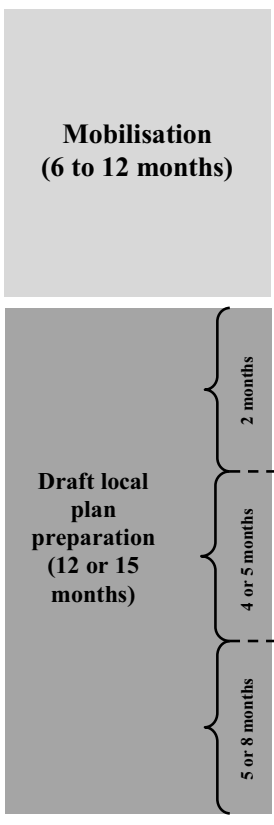

Publicity and public participation

Approval and gazette of Local Plan

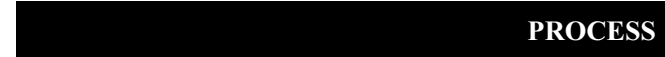

PROCESS

OUTCOME

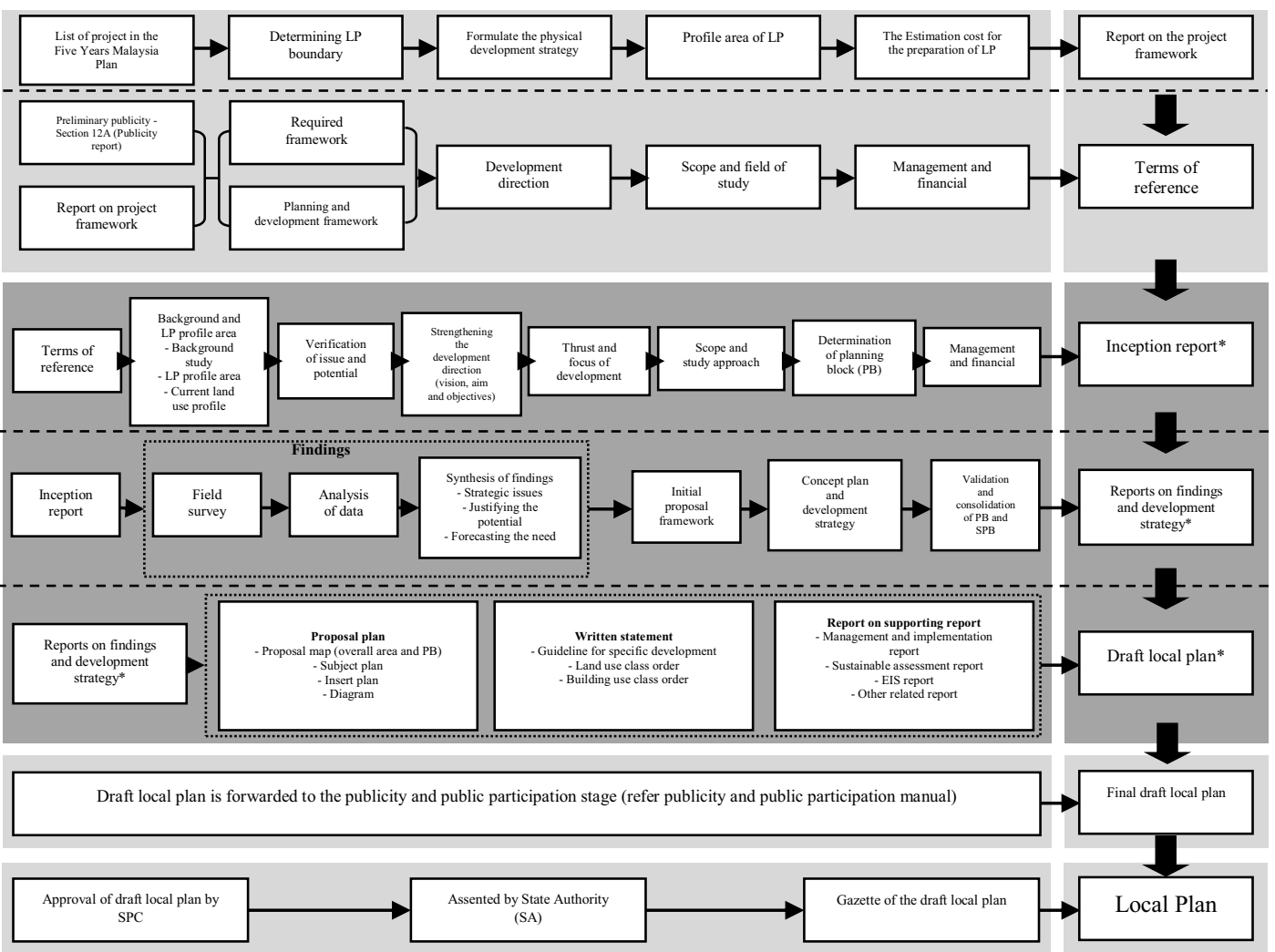

* Requires input for sustainability assessment

PB - Planning block

SPB - Small planning block

Figure 1. The Local Plan Preparation Process

Source: Adapted from Department of Town and Country Planning - Local Plan Manual (2009)

\subsection{The Existing Central Malacca Local Plan}

The Central Malacca Local Plan (2003 - 2015) has been gazetted in 2008. In the Central Malacca Local Plan (2003-2015), the coastal reclamation area is situated between Planning Block I and III. Yet, in the existing local plan, the problems concerning on the reclamation area and development process were encountered such as such as no detailed zoning for reclamation area as shown in Figure 2 [31].

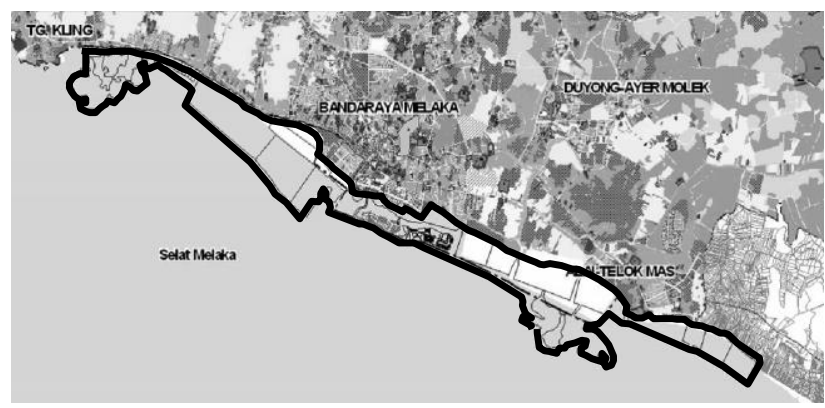

Figure 2. Current Land Use Zoning for Coastal Reclamation Area in the Central Malacca Local Plan 2003-2015

Source: Adapted from Central Malacca Local Plan 2003-2015
The lack of detailed zoning may lead to a conflict of land use and building in the future due to excessive unplanned development. Future problem may arise such as the duplication on the type of development and the non-continuity of the infrastructure allocation within reclamation development area as well as with the adjacent area [31]. Besides, another problem is that there is no specific guideline provided for coastal reclamation development. Currently, the development on the reclaimed land refers to the same guideline as planning for development on the 'original land'.

The reclaimed land and the original land are totally different especially in terms of land stabilisation and its durability. For example, the land can only stand with a certain level of building height. These problems will affect the decision making process towards planning permission for the development because it has no zoning and guidance that will deliver an efficient decision making process. As a result, the planning permission will be decided in ad-hoc manner. This portrays an unhealthy practice that will affect the long-term future development for reclamation area and its surrounding. These problems surely requires an immediate action from the state government and the local authority of the area in order to

\footnotetext{
${ }^{\mathrm{a}}$ Corresponding author: norsyafaah@gmail.com
} 
minimise the impact of the coastal reclamation development to its surrounding because currently, coastal reclamation in Malacca is being practices in ad-hoc manner. Thus, these scenarios revealed the importance of planning before development.

\section{Results and Discussion on the Significance of a Local Plan}

Local plan is used to control over the development through planning permission. The planning permission is the stage where it is required in proposing any development that requires planning permission and it should comply with the existing local plan of the area [18]. With the provision of local plan (the ahead planning) which demands for all current and forward planning that has been made beforehand, and all the relevant studies that has been conducted while preparing the local plan, thus, aligning the direction of the future development. The coastal reclamation development in Malacca is currently facing a rapid development [5]. However, due to the incomprehensive of the existing local plan of Central Malacca, it is unable to assist the development control for reclamation within the coastal area. Thus, this scenario leads to an ad-hoc manner in the decision making process. In any physical development, the development process should come after planning. Figure 3 illustrates the scenario in coastal reclamation development which reveals the consequences between planning and development.

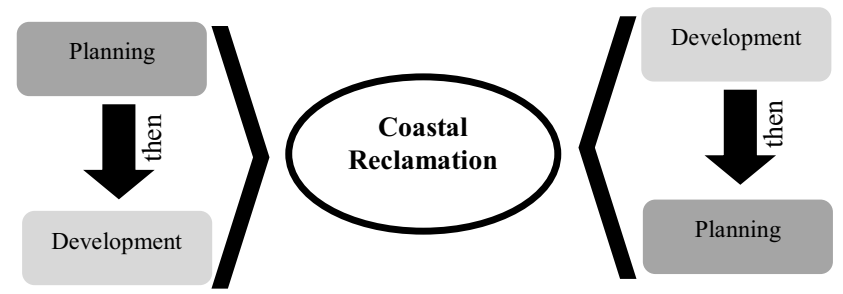

Figure 3. The consequences: planning first and development later or development first, planning later

\subsection{The Consequences: Planning First, Development Later}

Planning act as an important step especially in the development processes. It helps to plan for the future. In town planning context, planning is for the people. Litman [6] expresses planning as a social activity because it involves the people. The involvement of people through public participation offers an important element in planning because it allows plan to be viewed and considered from different perspectives and views, which then helps to identify arising problems early in the planning process as well as gaining support for the implementation of the plan $[37 ; 38]$.

The benefit is when it comes to the consideration to plan first such as planning for a development able to create a lasting value of sustainable development. The coastal reclamation development in Malacca started without a proper planning process and it can be considered as an ad-hoc manner. Additionally, the
Central Malacca Local Plan has been outdated because the local plan should only be effective until 2015. Due to that matter, the review for the existing local plan should be done according to the current situation and need for it to be reviewed.

\subsection{What if Development First, Planning Later?}

Development then later planning demonstrates an unhealthy practice. In West Malaysia, every development that can make changes to the land or building and may gives effect to its surrounding, therefore, is required to apply for planning permission from the respective local planning authority of the area as stated in Section 21(1) of Act 172. In addition to that, in Section 18(1) of Act 172 , every planning permission must follow the local plan of the area to plan for a development. However, if the requirement from the Act 172 cannot be fulfilled and the development is being approved even if it does not follow the local plan - the development control instrument, it may lead to the future consequences. For instance, the coastal reclamation development is a big project and it makes clear changes towards its surrounding, therefore, the planning for coastal reclamation requires an immediate action from the responsible planning authority in tackling this matter. Hence, it is better to prevent rather than facing future problems and disputes.

\section{Conclusions}

A local plan acts as a development control for a local planning authority. It plays an important role in the delivery of any development including within a reclamation land. Local Authorities are the responsible body to prepare and implement their local plans for their area. However, the coastal reclamation site in the Central Malacca faces challenges of the lack of detailed zoning for the area and the incompetence of the local plan itself in protecting the area especially for the purpose of planning permission. Results have shown that it is more fitting to perform planning earlier, before carrying out any development. The requirement on the provision of a local plan by a local planning authority in the Act 172 should be concurrent with the current situation and appropriate practices that should be as well applied in the law. The law must not be rigid and time consuming; however, it should be flexible and efficient with the current requirements and needs. Moreover, the Act 172 shall be amended as soon as possible especially for the reviewing and alteration of the local plan quickly. Another option, the interim development plan should be introduced to overcome this problem. Importantly, to plan and make a clear direction of the development for coastal reclamation in order to avoid future conflicts due to unhealthy planning practices that can caused inconvenience and disputes concerning on ad-hoc manner. Further work will include a more detail investigation on the delivery of development at the site. 


\section{Acknowledgement}

The authors would like to express their deep gratitude to the Research Management Centre (RMC) of Universiti Teknologi MARA (UiTM), Malaysia and the Ministry of Higher Education Malaysia for funding this research under the Research Acculturation Grant Scheme (Grant 600-RMI/RAGS 5/3 (135/2014).

\section{References}

1. Federal Ministry for Economic Cooperation and Development. Land Use Planning: Concept, Tools and Applications. Deutsche Gesellschaft fur Internationale Zusammenarbeit (GIZ) GmbH. (2012).

2. S. Ramly. Impact on the Coastal Areas of the Tanjung Tokong Land Reclamation Project, Penang, Malaysia: Effects on Wave Transformation, Sediment Transport, and Coastal Evolution. Division of Water Resources Engineering, Department of Building and Environmental Technology of Lund University. (2008).

3. K. S. Mohammed., Y. Elhadary., N. Samat and N. Oma. GIS and Remote Sensing Techniques for Measuring Agriculture Land Loss in Balik Pulau Region of Penang State, Malaysia. Asian Journal of Agriculture and Rural Development, 12. (2015).

4. Department of Statistics. Yearbook of Statistics Malaysia, 2010. Department of Statistics, Malaysia. (2011).

5. Malacca Historical City Council. Issues and Problems of Coastal Reclamation in Malacca. Central Malacca: Malacca Historical City Council. (2015).

6. T. Litman. Planning Principles and Practices. Victoria Transport Policy Institute. (2013).

7. C. R. Kothari. Research Methodology: Mothods \& Techniques. India: New Age International (P) Limited, Publishers. (2004).

8. S. Shamsuri. Research Methods for the Social Sciences (Made Simple). Selangor: DSS Publishing Enterprise. (2004).

9. M. Hammond and J. Wellington. Research Methods: The Key Concepts. Routledge Key Guides. (2013).

10. School of Distance Education. Social Research Methods: Core Courses. India: University of Calicut. (2011).

11. H. Hamdan and S. M. H. S. Subli. Perancangan dan Pembangunan Bandar. Shah Alam: Universiti Teknologi MARA (UiTM). (2012).

12. P.L. Stewart, R.J. Rutherford, H.A. Levy, and J.M. Jackson. A Guide to Land Use Planning in Coastal Areas of the Maritime Provinces. Canada: Department of Fisheries and Oceans. (2003).

13. L. Keeble. Principle and Practice of Town and Country Planning. London: Estate Gazette Ltd. (1969).
14. J. Ratcliffe. An Introduction to Town and Regional Planning. London: Hutchinson and Co. Publisher Ltd. (1974).

15. M. Yusup. Statutory Procedure and Planning Machinery for Urban Development in Sarawak. Shah Alam: Universiti Teknologi MARA (Shah Alam). (2013).

16. H. Zainol et al. Perspektif Perancangan. Perak: Pusat Penerbitan Universiti (UPENA), UiTM. (2009).

17. The Commissioner of Law Revision. National Land Code 1965 (Act 56). Selangor: International Law Book Services. (2011).

18. The Commissioner of Law Revision. Town and Country Planning Act 1976 (Act 172). Selangor: International Law Book Services. (2014a).

19. The Commissioner of Law Revision. Federal Constitution. Selangor: International Law Book Services. (2014b).

20. D. Omar and O. L. H. Leh. Malaysian Development Planning System: Kuala Lumpur Structure Plan and Public Participation. Asian Social Science, 30-36. (2009).

21. N. L. Pace. Resilient Coastal Development through Land Use Planning: Tools and Management Techniques in the Gulf of Mexico. University of Mississippi School of Law. (2013).

22. I. Ahmad and I. U. Bajwa. Regional Development Planning - Issues and Realities. 41st ISoCaRP Congress 2005, 2. (2005).

23. Department of Irrigation and Drainage. DID Manual: Volume 3 - Coastal Management. Kuala Lumpur: Department of Irrigation and Drainage. (2009).

24. C. B. Powter. Glossary of Reclamation and Remediation Terms Used in Alberta - 7th Editions. Alberta Environment, Science and Standards Branch, Edmonton, Alberta. (2002).

25. A. Sufian and M. Mustafa. Emerging Issues on Reclaimed Land in Malaysia: Alienation for Freehold or Leasehold?. International Seminar \& Indonesia Forum on Ocean Law and Resources: Building Comprehensive Perspective on National Security and Sustainable Development. Faculty of Law Brawijaya University. (2010).

26. R. Kolman and J.V. Hoff. Port Expansion through Land Reclamation. Port Technology International. Retrieved from www.port technology.org. (2012).

27. J. J. Jiao, S. Nandy and H. Li. Analytical Studies on the Impact of Land Reclamation on Ground Water Flow. Vol. 39, No. 6 - GROUND WATERNovember-December 2001, 912-920. (2001).

28. The Republic of Uganda. Uganda Vision 2040: The Local Government Development Planning Guidelines. Uganda: The Republic of Uganda. (2014).

29. S. M. Yusoff, F. Yusof and A. F. Arshad. An Analysis of Local Plan for Development Control at Local Planning Level in the State of Selangor. AcEBs 2014 Sabah ASEAN Conference on Environment-Behaviour Studies The Pacific Sutera 
Hotel, Sutera Harbour, Kota Kinabalu, Sabah, Malaysia, 04-05 January 2013 "Quality of Life in the Built and Natural Environment" (pp. 574-584). Selangor: Elsevier Ltd (2014).

30. The Commissioner of Law Revision. Local Government Act 1976 (Act 171). Selangor: International Law Book Services. (2014c).

31. Malacca Historical City Council. Central Malacca Local Plan (2003-2015). Central Malacca: Malacca Historical City Council. (2006).

32. A. A. Hussain. Kerajaan Tempatan: Teori dan Peranan di Malaysia. Kuala Lumpur: Dewan Bahasa dan Pustaka. (2002).

33. S. Khalil and S. A. Adelabu. Modelling Local Government System in Nigeria. Kuwait Chapter of Arabian Journal of Business and Management Review Vol. 1, No.1; September 2011, 136-154. (2011).

34. K. L. Miller. Advantages and Disadvantages of Local Government Decentralisation. Carribean Conference on Local Government and Decentralisation, 1-17. (2002).

35. Department of Town and Country Planning. Local Plan Manual. Selangor: Department of Town and Country Planning and Ministry of Urban Wellbeing, Housing and Local Government. (2009).

36. F. Ahmad, I. Mohd and W. N. W. A. Aziz. Land Use Planning and Property Development: Factors Affecting Urban Housing Development in Kuala Lumpur, Malaysia. 25th American Real Estate Society Meeting Monterey, California, USA. Kuala Lumpur: Centre for Studies of Urban and Regional Real Estate (SURE), Faculty of the Built Environment, Universuty of Malaya. (2009).

37. C. Schively, M. Beekman, C. Carlson and J. Reed. Enhancing Transportation: The Effects of Public Involvement in Planning and Design Processes. University of Minnesota, for the American Institute of Architects; at www.cts.umn.edu/pdf/CTS-0710.pdf. (2007).

38. Project for Public Spaces (PPS). A Citizen's Guide to Better Streets. Projects for Public Spaces. (www.pps.org): www.pps.org/pdf/bookstore/How_to_Engage_Your _Transportation_Agency_AARP.pdf. (2008). 